\title{
RESPONSES OF VEGETATION STAGES WITH WOODY DOMINANTS TO STRESS AND DISTURBANCE DURING SUCCESSION ON ABANDONED TAILINGS IN CULTURAL LANDSCAPE
}

\author{
PAVEL KovÁŘ, MiCHAL ŠTEFÁNEK, JAKUB MRÁZEK \\ Department of Botany, Charles University, Benátská 2, 12801 Prague 2, Czech Republic
}

Received: $7^{\text {th }}$ August 2011, Accepted: $25^{\text {th }}$ August 2011

\begin{abstract}
Studies of ecological succession on tailing containments (abandoned sedimentation basins with waste deposited by a factory producing sulphuric acid from pyrite ore) near the village of Chvaletice (Eastern Bohemia, Czech Republic) were carried out since 1973 with increased intensity and complexity between 1986 and 2002 (Kovář 2004). Vegetation cover in its relationships to various factors has been periodically monitored up to now. The abandoned ore-washery deposit is characterized by relative strong toxicity of the sediment material (high heavy metal content) and fluctuations of the microsite conditions up to extreme values ( $\mathrm{pH}$, salinity, surface temperatures). Species richness and the courses of some ecological processes are influenced both by availability of plant diaspores (regional species pool) determined with the presence of adequate dispersal mechanisms (anemochory, zoochory) and by the seasonal moderation of environmental variables excluding stress non-tolerant species at extreme epizodes and enabling survival of resistant species during the competition. Long lasting existence of patches without any vegetation together with herbaceous types of stands and woody successional stages create mosaics on the surface plateau. The oldest tree stands (in average $20-30$ years old) are predominantly formed by Populus tremula and Betula pendula, with minor admixture of Salix sp. div. (mainly S. caprea), Pinus sylvestris, Quercus robur or Cerassus avium, rarely Sarothamnus scoparius. The abundance ratio of two main dominants, aspen and birch, was changed for the benefit of the first one after the summer fire in extremely hot days. The effect of clonality on aspen regeneration and regrowth immediately after the fire disturbance was profitably manifested and it apparently facilitates the present state with aspen prevailing in the most forested tailing places at present, seventeen years after the fire. This fact supports the importance of clonal plant species role during primary succession.
\end{abstract}

Keywords: Vegetation succession, biodiversity, abandoned tailings, ore-washery sedimentation basin, substrate toxicity, salinity, fluctuation, fire disturbance, pattern of woody dominants, aspen, birch, environmental stress, regeneration, clonality 


\section{INTRODUCTION}

Development of biotas in degraded or otherwise altered parts of landscapes (Dobson et al. 1997, Montalvo et al. 1997, Palmer et al. 1997, Urbanska et al. 1999) represents a cluster of themes concentrated on biodiversity ecology and restoration perspectives. A part of this research is occuppied by cognition of criteria and circumstances of plant dominance within vegetation arising under the specific environmental extremes (Dost 1972, Antosiewics 1992, Stoutjesdijk and Barkman 1992, Vos and Opdam 1993). The process of primary succession in closed landfill sites (abandoned sedimentation basins or mine tailings for industrial deposits) establishes a functional community where they did not previously exist (e.g., Parker 1997). Environmental changes can be predicted based on important dominant organisms (e.g., Bertness and Callaway 1994) which determine the establishment of others (Bryndová and Kováŕ 2004, Kováŕ et al. 2004). Some species may fail to return into restored sites because of problems connected with limited opportunities for dispersal special effort must be made to provide opportunities for their return (Jiráčková and Dostál 2004). Alternating seasons with different meteorological characteristics (temperatures, moisture) in-between the years cause local decline of vegetational cover and usually correlate with peaks of local extinction of particular species or particular age category of perennials, mainly woody species (Kováŕ 1999). Birch is more tolerant to the extremeness of substrate conditions (e.g., $\mathrm{pH}$ and conductivity). Aspen colonized wet sites close to the basin centre which were better for plant growth. Trend of retrogressive trajectories of succession (Hobbs 1999) was observed on the studied deposits at places predisposed to drought in extraordinary dry growth seasons (Kovář 1994).

\section{MATERIAL AND METHODS}

\section{Habitat parameters of the locality}

Abandoned sludge sedimentation basin with ore deposits is located on the left bank of the Elbe River close to the abandoned surface quarry near Chvaletice in the northernmost part of the Železné hory hills. Geographical coordinates of the sedimentation basins are $50^{\circ}$ $02^{\prime} 12^{\prime \prime} \mathrm{N}$ latitude and $15^{\circ} 26^{\prime} 15^{\prime \prime} \mathrm{E}$ longitude. This old mining area is formed by granite with strata of Fe-Mn ores. During pyrite processing, high sulphur and phenol containing waste sludge was hydraulically transferred and deposited in three sedimentation basins. With increasing amounts of the waste material, it was necessary to elevate the side dikes which created the typical stage-shaped profile of the deposit pond. The mining and other works started in 1952 but the quarry was definitely closed in the mid-seventies. The sludge was mixed with water and transported a distance of 500 to 2,000 m into isolated areas of large-scale sedimentation basins with an overall area of 113 ha (Bulíček and Jindřich 1976). The area of the first and oldest basin is 40 ha and its capacity was $12,000,000 \mathrm{~m}^{3}$, the area of the second sedimentation basin is 36 ha and its capacity was also $12,000,000 \mathrm{~m}^{3}$. The third and the youngest basin, the planned capacity of which has never been achieved and which remained drained and unreclaimed since the first half of the 1980s, became the main experimental object monitored and tested for spontaneous processes of biological colonization of the deposited substrate.

The fire in August 1994 did not affect the whole area of the sedimentation basin. It was possible to distinguish three parallel successional series with different growth rates on plots untouched by fire (Kovár 1999). Three successional series were also studied in the burned area two years after the fire (Štefánek 1999): all successional series are described in Tab. 1. 
Table 1: Description of successional series monitored in the period 1996-1999 (Štefánek 1999).

\begin{tabular}{|c|c|c|c|c|}
\hline & & Woody species & $\mathbf{E}_{1}$ & $\mathbf{E}_{0}$ \\
\hline \multirow{3}{*}{ Unburned } & IN & $\begin{array}{l}\text { absence of taller woody } \\
\text { species; rarely small } \\
\text { seedlings of aspen } \\
(\text { Populus tremula })\end{array}$ & $\begin{array}{l}\text { dominant Calamagrostis } \\
\text { epigejos, occasionally } \\
\text { Phragmites australis }\end{array}$ & $\begin{array}{l}\text { more than } 80 \% \text { cover of } \\
\text { mosses, less lichens; } \\
\text { dominant Ceratodon } \\
\text { purpureus, Cladonia sp. } \\
\text { div. }\end{array}$ \\
\hline & IIN & $\begin{array}{l}\text { aspen (Populus tremula) } \\
\text { and birch (Betula } \\
\text { pendula) about } 1 \mathrm{~m} \text { high }\end{array}$ & Calamagrostis epigejos & $\begin{array}{l}\text { dominant lichens } \\
\text { (especially Cladonia } \\
\text { coniocraea) }\end{array}$ \\
\hline & IIIN & $\begin{array}{l}\text { birch (Betula pendula) } \\
\text { taller than } 1,5 \mathrm{~m}\end{array}$ & $\begin{array}{l}\text { rarely Calamagrostis } \\
\text { epigejos }\end{array}$ & $\begin{array}{l}\text { cover low, formed by } \\
\text { lichens (Cladonia } \\
\text { species) }\end{array}$ \\
\hline \multirow{3}{*}{ Burned } & IP & $\begin{array}{l}\text { only small sedlings of } \\
\text { aspen and birch }\end{array}$ & $\begin{array}{l}\text { dominant Calamagrostis } \\
\text { epigejos, presence of } \\
\text { another species (Vicia } \\
\text { hirsuta, V. tetrasperma, } \\
\text { Phragmites australis and } \\
\text { seedlings of woody } \\
\text { species) }\end{array}$ & $\begin{array}{l}\text { more than } 80 \% \text { cover of } \\
\text { mosses, less lichens; } \\
\text { dominant Ceratodon } \\
\text { purpureus, Cladonia sp. } \\
\text { div. }\end{array}$ \\
\hline & IIP & $\begin{array}{l}\text { aspen, rarely birch, more } \\
\text { than } 1 \mathrm{~m} \text { high }\end{array}$ & $\begin{array}{l}\text { presence of } \\
\text { Calamagrostis epigejos, } \\
\text { Vicia tetrasperma, V. } \\
\text { hirsuta, Phragmites } \\
\text { australis }\end{array}$ & $\begin{array}{l}\text { very low cover, less than } \\
10 \%\end{array}$ \\
\hline & IIIP & $\begin{array}{l}\text { dense growth of both } \\
\text { woody species (aspen } \\
\text { and birch) taller than } 2 \\
\text { meters }\end{array}$ & $\begin{array}{l}\text { presence of } \\
\text { Calamagrostis epigejos, } \\
\text { Vicia tetrasperma, } V . \\
\text { hirsuta, Phragmites } \\
\text { australis }\end{array}$ & very low \\
\hline
\end{tabular}

\section{Analytical methods}

All successional series are described in Tab. 1.24 permanent plots (size $0.5 \times 0.5 \mathrm{~m}$ ) were established two years after the 1994 fire (4 plots in each of the six successional series). Individuals of two wooden dominants, nonclonal birch (Betula pendula) and ramets of clonal aspen (Populus tremula) were recorded. Records were made three or four times every year, from May 1996 to July 1999 (for details see Štefánek 1999, 2004). Statistical analysis was made using multifactor analysis of variance with repeated measures (MANOVA), using a fixed effects model (Lepš 1996). Independent variables were the event (fire/without fire), successional series (I, II, III) and time, while the dependent variable was number of individuals of a particular species. Null hypothesis: each independent variable has no influence on the number of individuals of a particular species.

Relationships between chemical parameters of the substrate and growth of mentioned woody species were studied on four transects stretching from the central basin towards its margins (Mrázek 2002, 2004). Transect lengths ranged from 180 to 330 meters. The distance between the transects was about 70 meters. Plots $(2 \times 2 \mathrm{~m})$ were fixed every 25 meters alongside each transect, 42 altogether. Three substrate samples were taken from 
each plot for analysis and the parameters of birches and aspens (number of shoots and average height of growth) were measured.

Substrate samples for chemical analyses were collected in the form of 3 blocks in a particular plot, approx. $15 \times 15 \times 15 \mathrm{~cm}$ in size after the removal of the surface rough humus (usually 1- $5 \mathrm{~cm}$ deep). The sample period was September - November 2001. The substrate samples were drained at room temperature and sieved ( $2 \mathrm{~mm}$ mesh) for analysis. They were analyzed for $\mathrm{Mn}, \mathrm{Fe}, \mathrm{Al}$ and $\mathrm{Ca}$ by the AAS technique in Academy of Science of the Czech Republic, Institute of Botany - Analytical laboratory, Průhonice. Conductivity, pH and phosphorus were analysed by Charles University, Faculty of Science, Department of Botany - laboratory of geobotany unit. Content of phosphorus was measured by the Mehlich method (SPECOL 11, Carl Zeiss Jena, level $660 \mathrm{~nm}$ ), pH by Hanna instruments hi 9321 microprocessor $\mathrm{pH}$ meter and conductivity by Gryf 106 L III.

Two-way ANOVA or Kruskal-Wallis ANOVA (for nonparametric distributions) tests were used to analyse the spatial distribution of substrate characteristics. Relations among substrate parameters and plant growth were tested by redundancy analysis (RDA), a multivariate analysis, using CANOCO.

The effect of clonality on plant regeneration after disturbance was studied on twelve $2 \times 2 \mathrm{~m}$ plots. Prior to the experiment, all birches and aspens were removed from the plots, their numbers were recorded, and the height of each shoot measured. Then, a ditch was dug around half of the plots to interrupt the interconnections between the ramets of aspen inside and outside the squares. At the end of the experiment, all shoots were removed again, and the same observation made as at the beginning. The experiment took sixteen months, from March 2001 to June 2002.

On 9th July 2011 ten phytocoenological relevés in the oldest tree stands (about 5 meters tall) were recorded using seven-grade scale of abundance (Braun-Blanquet 1928). This was done 16 years after the fire on both the burned and unburned places in randomly distributed points.

Values of constancy (species frequence within this relevé set) expressed by five degree classes I - V, twenty percent of their extent each, are demonstrated for each species in particular vegetation layer $\left(\mathrm{E}_{0}, \mathrm{E}_{1}, \mathrm{E}_{2}, \mathrm{E}_{3}\right)$.

\section{RESULTS AND DISCUSSION}

\section{Comparison of vegetation development in burned and unburned plots}

The average number of individuals increased after the fire. The highest average number of individuals of Populus tremula was in the second successional series, the lowest number was in the third successional series. The average number of aspen individuals was slightly increasing during the observation period. (Fig. 1).

There were significant between-successional series differences in the number of individuals of Betula pendula. The lowest number of plants was in the first successional series, with average number of individuals being two and three times greater in the second and third successional series, respectively. There were no significant differences between burned and unburned plots and also no time effect was found (Fig. 2). 
Fig. 1: Average number of individuals of aspen (Populus tremula) on permanent plots in successional series during the observation period (May 1996-July 1999).

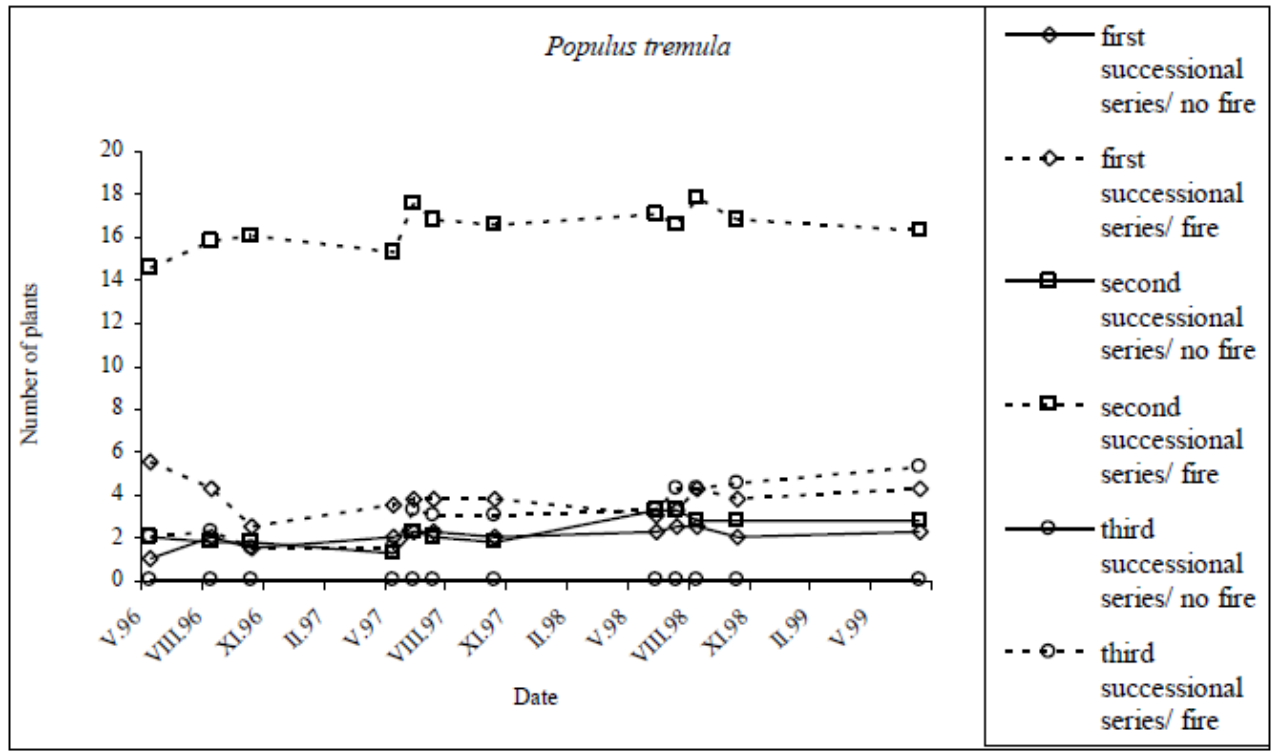

Fig. 2: Average number of individuals of birch (Betula pendula) on permanent plots in successional series during the observation period (May 1996-July 1999).

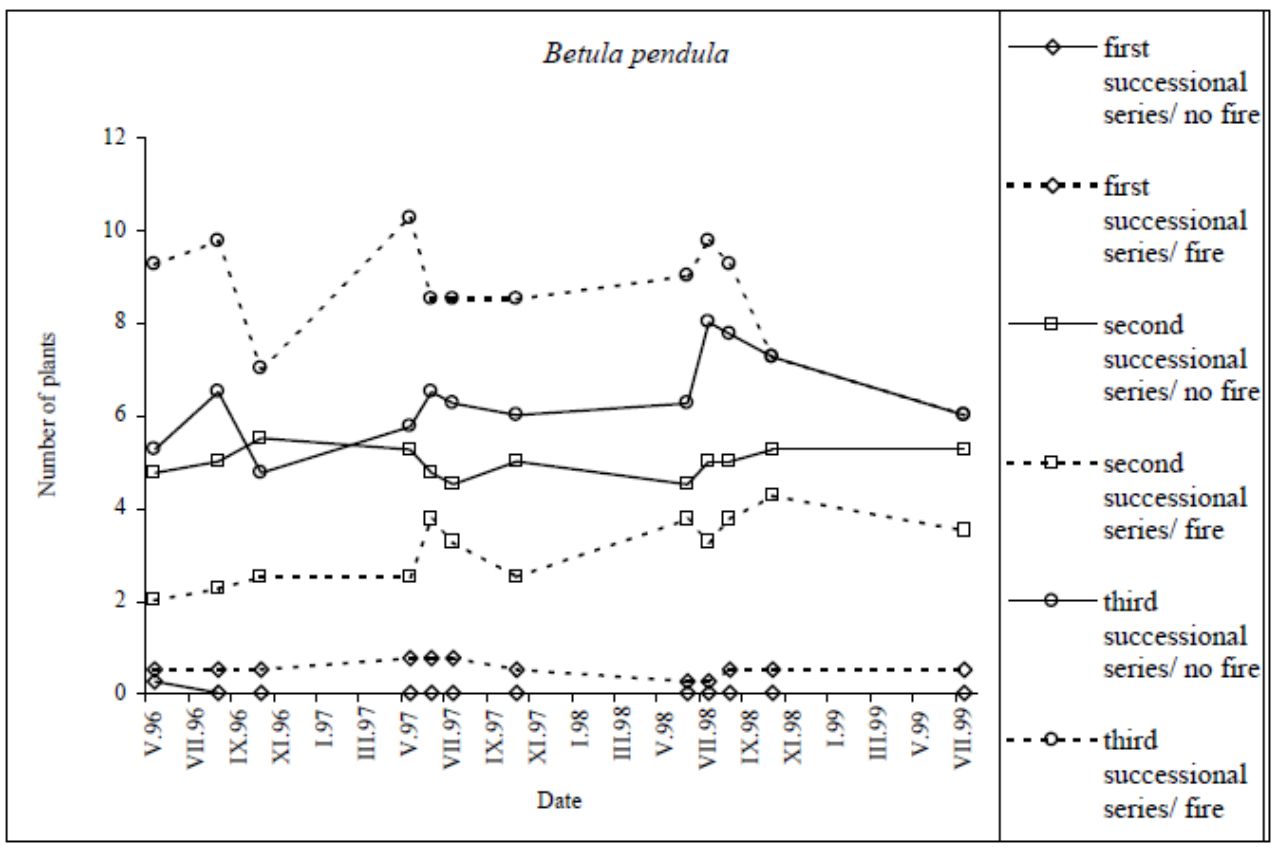


Fire usually changes vegetation in affected areas. These changes generally depend on the intensity of the fire (Bergeron 1991, Gloaguen 1993). Fire intensity is controlled especially by the amount of biomass (Ewing and Engle 1988) and the topography of the burned area (Turner et al. 1997). The response of individual species to fire can be categorized by the demographic mechanisms of the response; resprouting, clonal growth, seedling recruitment (Menges and Hawkes 1998). Clonal plants occur very often among the first species following initial phases of primary succession. They may very quickly occupy available space thanks to efficient vegetative propagation. The question arises how long time they sustain their dominance in the process of recovery in the ecotope in its successional trajectory.

Clonal grasses (Phragmites australis, Calamagrostis epigejos) and both below mentioned species of the Vicia genus as representatives of annuals (Vicia hirsuta, V. tetrasperma) occured almost entirely in the fire-affected areas. The significantly higher number of individuals of Populus tremula on burned plots was caused by increased sprout production. This type of response is quite a frequent response to fire and other disturbances. It is very common e.g. for shrubs in macchia or taiga forests (Gratoni and Amadori 1991, Johnson 1992). All species observed grew rapidly one year after the fire, but their growth ceased after several years. After quite a short time, a community similar to that on unburned plots was re-established. No significant differences in the number of individuals between burned and unburned plots were found for Betula pendula. This species is a non-clonal plant (Prach and Pyšek 1994, Martinková et al. 2001) responding to fire disturbance by regrowth from the trunk base of burned trees so that the number of "new" plants is controlled by the number of plants prior to the fire.

\section{Growth response of the wooden dominants to environmental conditions in the tailings surface and their spatial pattern}

The results may be divided into the following areas: (i) patterns related to spatial distributions of substrate characteristics, (ii) relationships between substrate characteristic and growth parameters of woody species, and (iii) intraclonal transport of elements in aspen and its role in succession.

Table 2: Results from analysis of variance and Kruskall-Wallis test (underlined) for difference among transects, significance at level 0.05 is only at content of Al.

\begin{tabular}{|l|c|}
\hline Substrate parameter & Significance level \\
\hline Content of Aluminium & 0.0051 \\
\hline Content of Manganese & 0.0832 \\
\hline Content of Phosphorus & 0.1153 \\
\hline Content of Iron & 0.1417 \\
\hline $\mathrm{pH}$ & 0.2275 \\
\hline Conductivity & 0.4158 \\
\hline Content of Calcium & 0.8489 \\
\hline
\end{tabular}

There was no significant difference in the distribution of substrate characteristics among the transects, with the only exception being the aluminium content (Tab. 2). 
Fig. 3: Spatial dependence in pH (a) and conductivity (b) scatter plots.

There is a strong dependence between substrate parameters and the position on the transects.

(a)

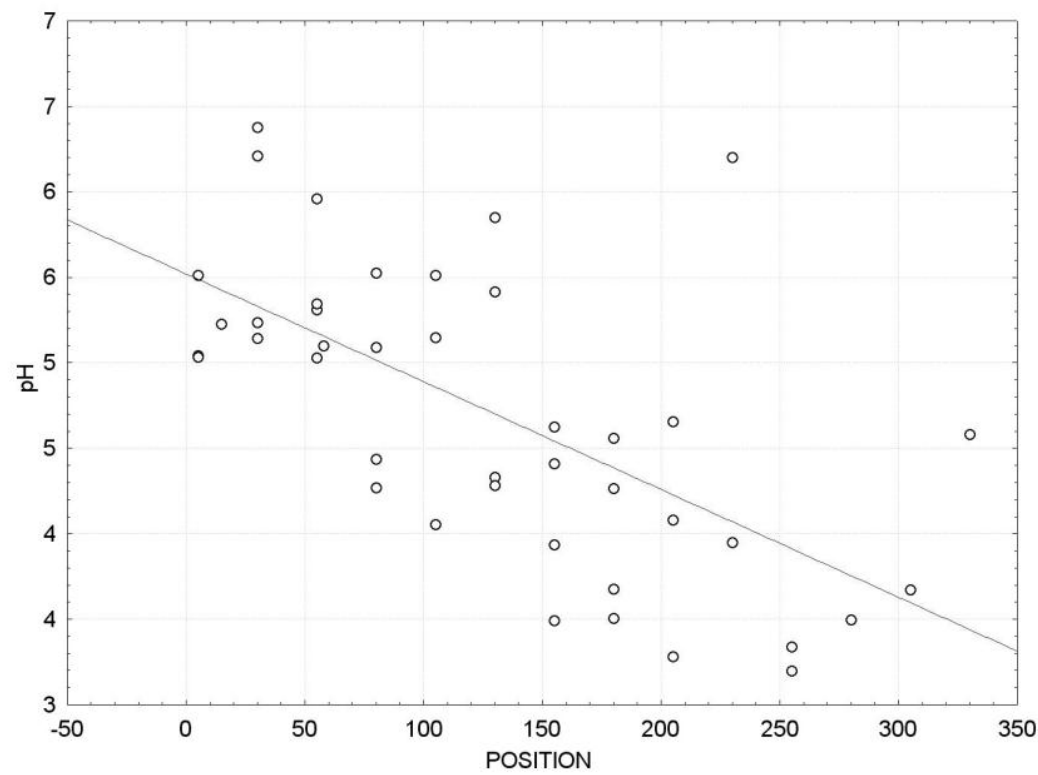

(b)

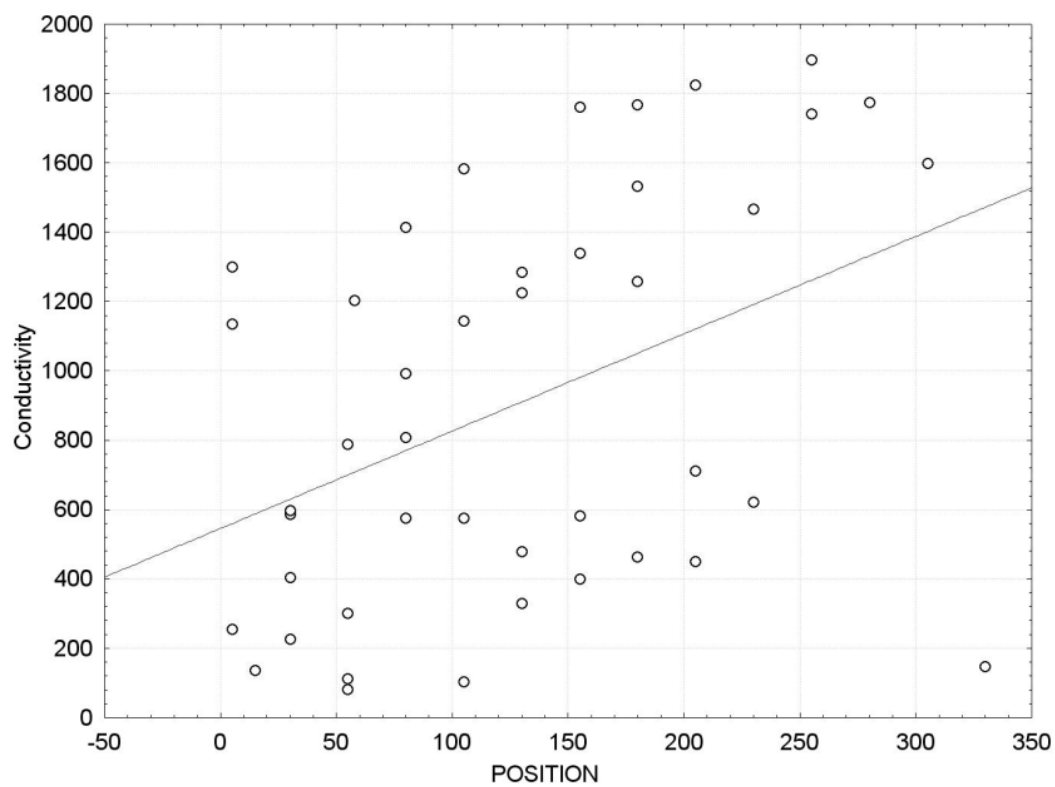


A gradient of spatial distribution was observed along the transect from the basin centre to its margins, being most distinct for $\mathrm{pH}, \mathrm{Fe}, \mathrm{P}$ and conductivity (Tab. 3, Fig. 3ab). Along this gradient, most of the characteristics increased except conductivity and Mn content.

Table 3: Results from GLM regression analysis dependence of substrate parameters on position. There is observed range of values on whole ore-washery in the third column.

\begin{tabular}{|l|c|l|}
\hline Substrate parameter & Significance level & Range of parameter \\
\hline $\mathrm{pH}$ & $4,3 \mathrm{e}-006$ & $3,2-6,38$ \\
\hline Content of Iron & 0,0037 & $15,21-805,2 \mathrm{mg} / \mathrm{kg}$ \\
\hline Content of Phosphorus & 0,0055 & $5,4-39,4 \mathrm{mg} / \mathrm{kg}$ \\
\hline Conductivity & 0,0056 & $0,082-1,897 \mu \mathrm{S} / \mathrm{cm}$ \\
\hline Content of Aluminium & 0,0275 & $8,08-177,91 \mathrm{mg} / \mathrm{kg}$ \\
\hline Content of Manganese & 0,0492 & $7,56-490,29 \mathrm{mg} / \mathrm{kg}$ \\
\hline Content of Calcium & 0,6233 & $306,25-13530 \mathrm{mg} / \mathrm{kg}$ \\
\hline
\end{tabular}

Spatial distribution of the substrate parameters was correlated with the measured parameters of trees (number of shoots, height) (Fig. 4). Results of the redundancy analysis show that the growth of both aspen and birch were correlated with $\mathrm{pH}$ and conductivity. The content of elements showed no important effect. Tree heights (both species) were influenced most by phosphorus content. Plots with higher $\mathrm{Mn}, \mathrm{Fe}$ and $\mathrm{Ca}$ contents hosted less vegetation (expressed by decreased number of shoots). The analysis explained $35.5 \%$ of the variability (first axis $21.4 \%$, second axis $14.1 \%$ ); the spatial variability was taken as a covariable.

Fig. 4: Correlation of the birch (Birch - number of shoots in plot, Gr B - height of growth) and aspen (Aspen - number of shoots in plot, $\mathrm{Gr} A$ - height of growth) with substrate factors. Results of the RDA analysis - spatial variables (position and transect) were calculated as covariables.

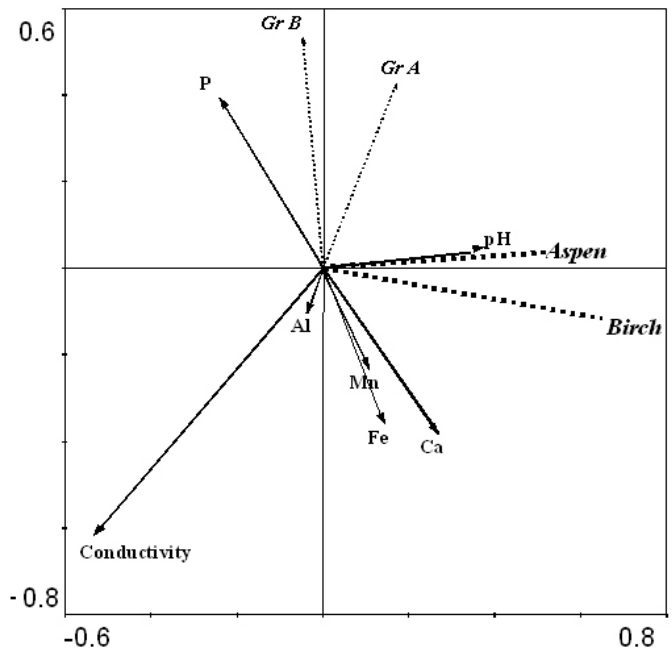


There was no statistically significant difference between the number of aspen shoots on treated vs. untreated plots. However, a trend was observed for increased number of aspen shoots on treated plots (Mrázek 2002). That could have been caused by lower apical dominance of the cut ramet than of the whole genet (Schmidt and Bazzaz 1987). Growth of aspen on plots with interrupted connections was significantly higher than on untreated plots. Also, aspen regenerated significantly more quickly than birch. The aspen/birch ratio was higher in the end than at the beginning of the experiment.

Dynamic development of vegetation structure in the sedimentation basin in Chvaletice depends on its drying (Kováŕ 2004). Although sources of diaspores of both species were present in the surroundings, birch seems to be more successful than aspen in the first stage of colonization. Birch is more tolerant of the extreme substrate conditions (e.g., pH and conductivity). Aspen colonized wet sites close to the basin centre which were more reasonable for plant growth.

The fire in 1994 deforested a large part of the basin and modified the vegetation structure. Rapid growth of aspen followed due to its ability to regenerate. Prior to the fire, birch growth somewhat lowered the extremes in substrate characteristics which also enabled a better growth of aspen. Miller (1984) observed that birch leaves improved the quality of the substrate. Aspen has recently dominated a wide strip along the centre of the basin. Its growth is very compact and slowly expands (mainly vegetatively) to the birch growth outside. This trend may proceed also in the future, especially in sites suitable for aspen. Thinning of tree growth and establishment of a dynamic community composed of birch and aspen could be predicted from those data (Mrázek 2004).

\section{Stands of wooden plant dominants after decades of spontaneous succession}

Vegetational succession stages are measured in decades, in some cases in centuries, and represent various changes within the process of speciation (McNeilly 1990). Ecological effects of toxicity in degraded and derelict industrial lands - ash deposits from power stations or human-made deserts - ore mining sites - are obvious in areas contaminated with heavy metals (e.g., Smith and Bradshaw 1979, Antosiewics 1992). The open surface of rough material is markedly differentiated into a variety of habitats within tens of years, from a totally smooth substrate without any plant seedlings to a dense jungle-like stand with prevailing grasses, shrubs and trees. The effectiveness of surface reclamation of several kinds is rather low and mixtures of added species slowly disappear being spontaneously replaced by stress-tolerant alien or native plants (Kovár 1994). Small-scale spatio-temporal dynamics of plant cover in open (toxic) substrate during the initial phase of primary succession in the abandoned ore-washery sedimentation basin widely differ between species, indicating very varying patterns in occupation of space (Kovár and Herben 2004). Most species, e.g., Phragmites australis, Salix spp. and Betula pendula, tend to occupy a site for a few years and then disappear. In these species, the temporal autocorrelation is never negative, indicating that once-occupied sites are not avoided by newly establishing individuals. This is different from Populus tremula and Calamagrostis epigejos. These species vary in their spatial persistence, but turn negative at large temporal lags, indicating that once-occupied sites are less likely to be colonized by newly establishing individuals than sites that have never been occupied.

Birch and aspen could serve as a good example of different ecological behaviour under the stress and disturbance conditions (Kovár and Herben 2004). The decrease in temporal autocorrelation of Populus tremula can be explained as a result of thinning of young seedlings compensated later by rejuvenation from root sprouts of surviving individuals or 
secondary tillers. This way, a relatively dense and homogeneous aspen stand, with shoot height about $0.5-1 \mathrm{~m}$, was formed prior to the mid-1990s, which could be a supporting factor in the ease with which the above treated midsummer fire in 1994 started. Distribution of Betula pendula was similar at the beginning of the monitored succession, however its ability to substitute above-ground biomass after exclusion of part of the individuals is strongly limited due to its non-clonal nature. This was probably one of the reasons why the proportion of young trunks after the 1994 fire rapidly shifted to a surplus of aspen (Populus tremula). The successional trajectory may be altered by a specific disturbance with particular adjacent effects (nutrient release, invasion of new groups of fungi or seedtransporting organisms). In our case, the aspen dominance at present stage of the stand development exhibits clear relationship to the occurrence of massive burning which implies different results than the other observations based on wider screening of localities with Betula pendula, Salix caprea and Pinus sylvestris as the most common woody species dominated in human-made habitats (Prach et al. 2008).

The following woody vegetation characterized by actual range of 10 phytocoenological records of the oldest successional phase in the Chvaletice tailings (total cover, classes of constancy, variations of abundance, 9th July 2011) illustrates the current stage of spontaneous vegetation succession after the abandonment without artificial rehabilitation (30 years ago) and after the fire (17 years ago):

$\mathrm{E}_{3}$ (total cover: 50 - $80 \%$ ): Populus tremula L. V(1 - 4), Betula pendula Roth.V(+ - 4)

$\mathrm{E}_{2}$ (total cover: $\left.10-40 \%\right)$ : Populus tremula L. V(+ - 3), Betula pendula Roth.V(+ - 3), Quercus robur L. IV(r - +), Pinus sylvestris III( $(\mathrm{r}-+)$, Salix caprea L. II(r - +), Salix aurita L. I(r), Prunus avium (L.)L. II(r - +), Tilia cordata Mill. I(r), Populus alba L. I(r)

$\mathrm{E}_{1}$ ( total cover: 5 - $30 \%$ ): Calamagrostis epigejos (L.)Roth.V(+ - 3), Phragmites australis (Cav.)Steud. III( $\mathrm{r}-+)$, Agrostis stolonifera L. III( $\mathrm{r}-+)$, Holcus lanatus L. III( $\mathrm{r}$ + ), Festuca rubra L. II(r - +), Vicia tetrasperma (L.)Schreber II(r - +), Silene alba II(r - +), Vicia hirsuta (L.)S.F.Gray I(r - +), Hieracium sabaudum L. I(r - +), Odontites ruber Besser $\mathrm{I}(\mathrm{r}-+)$, Artemisia vulgaris L. I(r - +), Poa compressa L. I( $\mathrm{r}-+)$, Erigeron annuus (L.)Pers. $\mathrm{I}(\mathrm{r}-+)$, Impatiens parviflora DC. I(+), Anthoxanthum odoratum L. I(+), Lotus corniculatus L. I(r), Geum urbanum L. I(r), Hypochaeris radicata L. I(r), Lapsana communis L. I(r), Chelidonium majus L. I(r), Arctium tomentosum I(r), Chaerophyllum bulbosum L. I(r), Leucanthemum ircutianum DC. I(r), Cirsium vulgare (Savi) Ten. I(r), Rumex thyrsiflorus Fingerh. I(r), Vicia cracca L. I(r), Conyza canadensis (L.) Cronquist I(r), Daucus carota L. I(r), Plantago major L. I(r), Dryopteris filix-mas (L.)Schott I(r)

$\mathrm{E}_{0}$ (total cover: $\left.1-10 \%\right)$ : Cladonia rei Schaerer V(r - +), Cladonia humilis (With.)Laund. III(r - +), Cladonia furcata (Huds.)Schrad. I(r), Ceratodon purpureus (Hedw.)Brid. IV(r $+)$, Polytrichum juniperinum Hedw.) II( $\mathrm{r}-+)$, Brachythecium salebrosum (Web. et Mohr) Br. Eur. II(r - +), Pleurozium schreberi (Brid.)Mitt. I(+), Bryum caespiticium Hedw. I(r), Dicranum polysetum Sw. I(r)

Species substitution over a longer time period may resemble spiral cycles with alternating low herb and woody dominants and/or their cohorts influenced by extinction and new establishment of seedlings (Kovár 1994). Spatial dynamics of this process depends on the weathering rates of the mineral material on the topsoil and litter decomposition (Rauch 2004, Kovářová and Frantík 2004). There is a difference between succession on the sandy- 
like substrate in the ash-slag deposits, which is closer to a secondary succession, with higher diversity of herb species before establishment of a woody stand, and the more extreme ore-washery substrate supporting poor woody stands with only a few resistant herbs and/or grasses and some cryptogams in the younger successional stages (Kovár 2004). The latter coincides more with the features of primary succession.

From the viewpoint of restoration practice, the process of succession is surely the cheapest way of reclamation of the habitat type described in this study. Another positive aspect of natural succession is the selection of species which can grow and reproduce there. However, without man's help the process of succession might be too long and species with ineffective dispersal would have only a small chance to colonise the site. Therefore, it is recommended to enhance the establishment of vegetation nuclei (McClanahan 1986, Robinson and Handel 1993, Jandová et al. 2009) with the presence of later successional species. These may serve as local sources of diaspores as well as support for bird seed dispersers carrying the ingested diaspores from outside. Another implication of this type of "new wilderness" in fragmented cultural landscape could be its use within ecological networks (Jongman 2008).

\section{CONCLUSIONS}

There was a fire in August 1994 on the abandoned ore-washery sedimentation basin in Chvaletice which partly affected the vegetation of the surface plateau area. Six plant dominants, Calamagrostis epigejos, Phragmites australis, Populus tremula, Betula pendula, Vicia hirsuta and Vicia tetrasperma formed the vegetation cover of the sedimentation basin after the fire episode. Significantly higher numbers of individuals of aspen (Populus tremula) were recorded on the burned plots. On the other hand, the number of birch individuals (Betula pendula) did not significantly vary between the burned and unburned plots (Štefánek 2004).

The growth patterns of two dominant woody species were related to the selected chemical characteristics of the substrate $(\mathrm{pH}$, conductivity as a measure of salinity, and contents of $\mathrm{P}, \mathrm{Fe}, \mathrm{Mn}, \mathrm{Al}, \mathrm{Ca}$ ). The effect of clonality on aspen regeneration and regrowth following disturbance was also studied. Of particular interest was the role of nutrient transport between ramets on disturbed vs. non-disturbed sites (Mrázek 2004). Most substrate parameters changed along transects from the central basin towards its margin, with conductivity, $\mathrm{Al}$ and $\mathrm{Fe}$ contents increasing, while $\mathrm{pH}$ and $\mathrm{Mn}$ content decreased which indicates spatial changes in the toxic stress by the substrate. After disturbance, aspen regenerated easier than birch. The results of the development of the stand after next 17 years are documented by series of actual vegetational records in 2011. It seems to be apparent the unifying trend of the woody stand development from the original differentiated several successional series registered in younger successional stages.

\section{ACKNOWLEDGEMENTS}

The work has been supported by the grant no. 206/93/2256 of the Grant Agency of the Czech Republic „Biotic interactions during vegetation succession on toxic substrates” and by the research project MSM 113100004, chapter „Ecological plasticity and taxonomical variability of expansive plant species" of the Czech Ministry of Education. 


\section{REFERENCES}

Antosiewicz, D. M. (1992). Adaptations of plants to an environment polluted with heavy metals. Acta Soc. Bot. Polon., 61(2): 281-299.

Bergeron, Y. (1991). The influence of island and mainland lakeshore landscapes on boreal forest fire regimes. Ecology, 72: 1980-1992.

Bertness, M. D., Calaway, R. (1994). Positive interactions in communities. Tree, 9:191193.

Braun-Blanquet, J. (1928). Pflanzensoziologie. Springer Verlag, Berlin.

Bryndová, I., Kováŕ, P. (2004). Dynamics of the demographic parameters of the clonal plant Calamagrostis epigejos (L.) Roth in two kinds of industrial deposits (Abandoned sedimentation basins in Bukovina and Chvaletice). In: Kovár̆, P. (Ed.): Natural Recovery of Human-Made Deposits in Landscape (Biotic Interactions and Ore/Ash-Slag Artificial Ecosystems). pp. 267-276. Academia, Prague

Bulíček, J., Jindřich, J. (1976). Hydro-economical problems of sedimentation basins. SZN, Prague [in Czech].

Dobson, A. P., Bradshaw, A. D. \& Baker, A. J. M. (1997). Hopes for the future: restoration ecology and conservation biology. Science, 277: 515-522.

Dost, H. (1972). Acid sulphate soils. Wageningen, IIFLRI

Ewing, A. L., Engle, D. M. (1988). Effects of late summer fire on tallgrass prairie microclimate and community composition. Am. Midl. Nat., 120: 212-223.

Gloaugen, J. C. (1993). Spatio-temporal patterns in post-burn succession on Brittany heathlands. Journal of Vegetation Science, 4: 561-566.

Hobbs, R.J. (1999). Restoration of disturbed ecosystems. In: Walker, L.R. (Ed.): Ecosystems of disturbed grounds, Ecosystems of the world 16, pp. 673-687, Elsevier, Amsterdam.

Jandová, L., Sklenář, P. \& Kovář, P. (2009). Changes of grassland vegetation in surroundings of new railway flyover (Eastern Bohemia, Czech Republic). Part I:Plant communities and permanent habitat plots. Journal of Landscape Ecology, 2(1): 36-57.

Jiráčková, M., Dostál, P. (2004). Microsite versus dispersal limitation in primary succession: a case study from an abandoned ore-washery sedimentation basin. In: Kovár̆, P., (Ed.): Natural Recovery of Human-Made Deposits in Landscape (Biotic Interactions and Ore/Ash-Slag Artificial Ecosystems). pp. 59-76. Academia, Prague

Jongmann, R. (2008). Ecological networks are an issue for all of us. Journal of Landscape Ecology, 1(1): 7-13.

Johnson, E. A. (1992). Fire and vegetation dynamics: studies from the North American boreal forest. Cambridge University Press, Cambridge, N.Y.

Kováŕ, P. (1994). Vegetation monitoring and restoration ecology in landscape: Changes on sediment deposits at Chvaletice (Central Bohemia - Labe River Basin). Príroda, 79-96. [in Czech]

Kováŕ, P. (1999). Biotic interactions and restoration ecology of abandoned sedimentation ponds of toxic materials. In: Kovář, P. (Ed.): Nature and Culture in Landscape Ecology (Experiences for the 3rd Millennium), pp. 290-302, The Karolinum Press, Praha.

Kováŕ, P. (2004): Trends in spontaneous biological renaturation of human-made deposits: Background for restoring management. In: Kovár, P. (Ed.): Natural Recovery of Human- 
Made Deposits in Landscape (Biotic Interactions and Ore/Ash-Slag Artificial Ecosystems). pp. 337-351. Academia, Prague

Kovár, P., Herben T. (2004). Small-scale spatiotemporal dynamics of plant cover during the initial phase of primary succession in an abandoned ore-washery sedimentation basin. In: Kovár,, P. (Ed.): Natural Recovery of Human-Made Deposits in Landscape (Biotic Interactions and Ore/Ash-Slag Artificial Ecosystems). pp. 277-284. Academia, Prague,

Kovář, P., Štěpánek, J. \& Kirschner, J. (2004). Clonal diversity of Calamagrostis epigejos (L.) Roth in relation to type of industrial substrate and successional stage. In: Kovár, P. (Ed.): Natural Recovery of Human-Made Deposits in Landscape (Biotic Interactions and Ore/Ash-Slag Artificial Ecosystems). pp. 285-293. Academia, Prague,

Kováŕová, M., Frantík, T. (2004). Decomposition of organic matter on different substrates - laboratory study. In: Kovář, P. (Ed.): Natural Recovery of Human-Made Deposits in Landscape (Biotic Interactions and Ore/Ash-Slag Artificial Ecosystems). pp. 153-175. Academia, Prague

Lepš, J. (1996). Biostatistics. - Jihočeská univerzita, České Budějovice. [in Czech]

Martinková, M., Maděra, P. \& Úradníček, L. (2001). Strategy of birch (Betula L.) in substitute stands of the Krušné hory Mts., air-polluted region. Journal of Forest Science, 47 (Special Issue): 87-95.

McClanahan, T. R. (1986). The effect of a seed source on primary succession in a forest ecosystem. Vegetatio, 65: 175-178.

McNeilly, T. (1990). Evolutionary lessons from degraded ecosystems. In: Jordan, III W.R., Gilpin, M.E. \& Aber, J.D. (Eds.): Restoration ecology. A synthetic approach to ecological research. pp. 271-286. Cambridge University Press, Cambridge

Menges, E. S., Hawkes C. V. (1998). Interactive effects of fire and microhabitat on plants of Florida Scrub. Ecol. Appl., 8: 935-946.

Miller, H. G. (1984). Nutrient cycles in birchwoods. Proceedings of the Royal Society of Edinburgh, 85B: 83-96

Montalvo, A. M. (1997). Restoration biology: a population biology perspective. Restoration Ecology, 5: 277-290.

Mrázek, J. (2002). Růst břizy Betula pendula a osiky Populus tremula na toxickém substrátu rudního odkaliště. MSc Thesis. Charles University in Prague, Faculty of Science, Department of Botany, $66 \mathrm{p}$.

Mrázek, J. (2004). Comparison of the growth of dominant trees (Betula pendula, Populus tremula) in primary succession on toxic substrate. In: Kovář, P. (Ed.): Natural Recovery of Human-Made Deposits in Landscape (Biotic Interactions and Ore/Ash-Slag Artificial Ecosystems). pp. 294-299. Academia, Prague,

Palmer, M. A., Ambrose, R. F. \& Poff, N. L. (1997). Ecological theory and community restoration ecology. Restoration Ecology, 5: 291-300.

Parker, V. T. (1997). The scale of successional models and restoration objectives. Restoration Ecology, 5: 301-306.

Prach, K., Pyšek, P. (1994). Spontaneous establishment of woody plants in Central European derelict sites and their potential for reclamation. Restoration Ecology, 2: 190 197. 
Prach, K., Bastl, M., Konvalinková, P., Kováŕ, P., Novák, J., Pyšek, P., Řehounková, K. \& Sádlo, J. (2008). Vegetation succession in human-made habitats in the Czech Republic survey of dominant species and stages. Príroda, 26: 5-26. [in Czech]

Rauch, O. (2004). Genesis and characteristics of orewaste sulphate soils at Chvaletice. In: Kovár̆, P. (Ed.): Natural Recovery of Human-Made Deposits in Landscape (Biotic Interactions and Ore/Ash-Slag Artificial Ecosystems). pp. 45-58. Academia, Prague,

Robinson, R. R., Handel, S.N. (1993). Forest restoration on a closed landfills: Rapid addition of new species by bird dispersal. Conservation Biology, 7(2): 271-278.

Schmid, B., Bazzaz, F. A. (1987). Clonal integration and population structure in perennials: Effects of severing rhizome connections. Ecology, 68: 2016-2022.

Smith, R.A.H., Bradshaw, A.D. (1979). The use of heavy metal tolerant plant populations for the reclamation of metalliferous wastes. J.App.Ecol., 16: 595-612.

Stoutjesdijk, Ph., Barkman, J. J. (1992). Microclimate, vegetation and fauna. Opulus Press, Uppsala.

Štefánek, M. (1999). Obnova vegetace na odkališti po disturbanci požárem. MSc Thesis. Charles University in Prague, Faculty of Science, Department of Botany, 67 p.

Štefánek, M. (2004). Secondary succession after fire on an abandoned ore-washery sedimentation basin - different trajectories (A comparison with primary succession). In: Kováŕ, P. (Ed.): Natural Recovery of Human-Made Deposits in Landscape (Biotic Interactions and Ore/Ash-Slag Artificial Ecosystems). pp. 248-266. Academia, Prague

Turner, C. L., Blair, J. M., Schartz, R. J. \& Neel, J. C. (1997). Soil N and plant responses to fire, topography, and supplemental $\mathrm{N}$ in tallgrass prairie. Ecology, 78: 1832-1843.

Urbanska, K. M., Webb, N. R. \& Edwards, P. J. (1999). Restoration ecology and sustainable development. Cambridge Univ. Press, Cambridge.

Vos, C. C., Opdam, P. (1993). Landscape ecology of a stressed environment. Chapman \& Hall, London.

Whelan, R. J. (1995). The ecology of fire. Cambridge Studies in Ecology, Cambridge University Press, NY.

Walker, L.R., del Moral R. (2003). Primary succession and ecosystem rehabilitation. Cambridge Univ. Press, Cambridge. 